\title{
Nutrient Composition and Characteristics of Cow Milk Yogurt with Different Additional Fruit and Storage Time
}

\author{
Putri Dian Wulansari and Andri Kusmayadi \\ Study Programe of Animal Science, University of Perjuangan Tasikmalaya, Jl. Peta No 177 Tasikmalaya, Indonesia \\ Corresponding author email: callmeuput@gmail.com
}

\begin{abstract}
This research was aimed to evaluate the composition (total solids, water content, fat and protein), qualitative properties (color, aroma, and texture) and quantitative properties (free fatty acid and lactic acid) of cow milk yogurt with different fruits addition and storage time. Experimental method applied Completely Randomized Design with five treatments namely control, dragon fruit, mango, apple and banana $(20 \% \mathrm{v} / \mathrm{v})$, each with 5 replicates. Qualitative characteristic assessment was conducted on 0, 5, 10 and 15 days of storage. Result showed that fruit addition significantly affected the composition and characteristics, while storage time significantly affected quantitative characteristics of yogurt. Apple and banana increased $13 \%$ total solids of plain yogurt, while the highest fat content $(4.516 \%)$ was observed in control yogurt which had the lowest protein content $(2.564 \%)$. The highest free fatty acid was in control yogurt ripen for 15 days $(22.885 \%)$ while the lowest free fatty acid was in mango yogurt ripen for 10 days (13.915\%). Fruit addition in yogurt ripen for 15 days at $5 \mathrm{C}$ resulted in a safe consumed product.
\end{abstract}

Key words : yogurt, fruit yogurt, cow milk, storage

Abstrak. Penelitian bertujuan mengevaluasi komposisi (total solids, kandungan air, lemak, dan protein) dan sifat kualitatif (warna, bau, dan tektur) dan kuantitatif (free fatty acid dan kadar asam laktat) yogurt dari susu sapi dengan penambahan buah dan lama penyimpanan yang berbeda. Metode penelitian eksperimental menggunakan Rancangan Acak Lengkap dengan lima perlakuan yaitu kontrol (yogurt plain), buah, mangga, apel dan pisang (penambahan buah sebanyak $20 \% \mathrm{v} / \mathrm{v}$ ). Masing-masing perlakuan dilakukan pengulangan sebanyak 5 kali. Pengujian kualitatif dilakukan pada umur penyimpanan 0, 5, 10, dan 15 hari. Hasil penelitian menunjukkan bahwa penambahan buah berpengaruh nyata terhadap komposisi dan sifat kualitatif begitu juga lama penyimpanan berpengaruh nyata terhadap sifat kuantitatif yogurt. Penambahan buah apel dan pisang meningkatkan total solid sebanyak $13 \%$ dari yogurt plain, sedangkan kandungan lemak paling tinggi $(4,516 \%)$ dihasilkan oleh yogurt kontrol, berbanding terbalik dengan kandungan protein yang dihasilkan, yaitu yogurt kontrol menghasilkan kandungan protein paling rendah (2,564\%). Free fatty acid yang paling tinggi dihasilkan pada yogurt kontrol dengan lama penyimpanan 15 hari (22,885\%) sedangkan free fatty acid paling rendah dihasilkan oleh yogurt dengan penambahan buah mangga pada umur penyimpanan 10 hari $(17,588 \%)$. Kadar asam laktat paling tinggi dihasilkan oleh yogurt mangga pada penyimpanan 15 hari (21,293\%) sedangkan paling rendah pada yogurt plain pada penyimpanan 10 hari (13,915\%). Penambahan buah menghasilkan produk yang aman untuk dikonsumsi dengan masa simpan 15 hari pada suhu $5^{\circ} \mathrm{C}$.

Kata kunci : yogurt, yogurt buah, susu sapi, penyimpanan

\section{Introduction}

Yogurt is a trending fermented milk product in society due to the many benefits of consuming yogurt. The benefits are (1) improving lactose absorption in lactose intolerant patient and heal diarrhea (Kolars et al., 1984; Guarner et al., 2005), (2) improving lactose tolerance and decreasing body weight (body fat loss) (McKinley, 2005), (3) lowering cholesterol (Marete et al., 2010), (4) improving body immune, minimizing digestive inflammation symptoms, increasing productivity, nutrient intake and tolerance to antiretroviran in HIV patient (Irvine et al., 2010), (5) improving metabolism, preventing chronical inflamation disorder, intestin functional disorder, infection and alergy (Rijkers et al., 2010). (6) maintaining the balance of intestine and urogenital flora, preventing colon irritation, 
constipation, urogenital infection, osteoporosis, anorexia nervosa and premenstruation syndrome, warding off menopause and improving bone health (Vrese, 2009).

Yogurt product has various market segments namely fruits flavoured, low calorie yogurt, whipped yogurt, mild yogurt, hard and soft yogurt, yogurt drink, yogurt with probiotic culture, long life yogurt, yogurt for breakfast dan yogurt for toodlers (Chandan, 2006). Various types of yogurt are set yogurt, stirred yogurt, sweet drinking yogurt, fruit yogurt, yogurt cheese, frozen yogurt dan dried yogurt (Yildiz, 2010).

From all yogurt categories, $74 \%$ is yogurt mixed with fruit (fruit yogurt). Additional fruit flavor, pure fruit of fruit extract can improve taste, color and texture flexibility of yogurt to consumers. Fiber in the fruit adds more benefit when consuming fruit yogurt namely preventing colon disease. Some fruits even contain antioxidant. Fruit yogurt give a more healthy benefit. Fruit addition in yogurt improve taste and nutrition value of the yogurt. Fruit yogurt also plays a significant role in the rate of yogurt selling and consumption (Cakmakcii et al., 2012).

Yogurt characteristics based on SNI 01-29812009 are containing $12 \%$ total solids. The contributing factors to yogurt produced are milk total solids, milk composition, homogeny, the types of starter bacteria, pasteurization, fermentation process and temperature during incubation (Magenis et al., 2006; Lee and Lucey, 2010). The addition of dragon fruit, mango, apple and banana with different composition is assumed to affect the final yogurt product. Total solids of dragon fruit is $12.50 \%$ (To et al., 2000), mango is $16 \%$ (Mulyawanti et al., 2008), apple is $17.08 \%$ and banana is $17.51 \%$ (Mahmood et al., 2008). Adding fruit with different total solids in yogurt is expected to affect the characteristics and total solids of the fruit yogurt.

\section{Materials and Method}

The research used 50 liters of fresh cow milk obtained from Pratama Trading farm, Sindangkasih district, Ciamis region West Java. Culture starter used was dry starter containing Streptococus termophillus, Lactobacillus acidophillusand Lactobacillus bulgaricus. The fruits added were dragon fruit, mango, apple and banana $2 \mathrm{~kg}$ each. Substances for chemical analysis included aquadest, $\mathrm{NaOH}$, alcohol, phenolptalin solution, buffer 4 and 7 and other chemicals for protein and lipid analysis.

The Research were designed by Completely Randomized Design method (Steel and Torrie, 1996) with five replicates and the treatments were fruit addition (zero fruit/control, dragon fruit, mango, apple and banana). Research procedure started with milk pasteurization using HTST (High Temperature Short Time), milk temperature was lowered to $45^{\circ} \mathrm{C}$, added with $10 \%$ culture bacteria, and incubated for $6 \mathrm{~h}$ at $45^{\circ} \mathrm{C}$. The yogurt product was added with $20 \%$ $(\mathrm{v} / \mathrm{v})$ of each treatment for qualitative properties analysis at $0,5,10$ and 15 days of storage.

\section{Results and Discussion}

\section{Composition}

The obtained data showed that different fruits added to the yogurt affected water content, total solids, fat and protein content ( $P>0.01$ ) (Table 1). Apple and banana produced yogurt with the highest total solids (14.376\%). Previous findings indicated different fruits had different composition and total solids namely $12.50 \%$ in dragon fruit (To et al., 2000), $16 \%$ in mango (Mulyawanti et al., 2008), $17.08 \%$ in apple and $17.51 \%$ in banana (Mahmood et al., 2008). Apple and banana addition with $17.3 \%$ total solids resulted in fruit yogurt with the highest total solids (14.376\%) or increasing 13\% total solids from control yogurt. 
Fat and protein content is affected by different fruits added in the yogurt $(P>0.01)$ (Table 1). The highest fat content was in control yogurt (4.516\%); in contrast, the lowest protein content $(2.564 \%)$ was also in control yogurt. This finding reported a higher total solids and fat content but lower protein than that of Ozer (2006) namely $13.85 \%$ vs $12.5 \%, 3.57 \%$ vs $3.3 \%$, and $3.27 \%$ vs $3.9 \%$ respectively.

The contributing factors of yogurt are total solids, milk composition, homogeny, types of starter bacteria, pasteurization, fermentation process and temperature (Magenis et al., 2006, Lee and Lucey, 2010). Research result indicated that additional fruit with different total solids affected the yogurt product.

\section{Characteristics}

Characteristics of yogurt is determined in qualitative and quantitative. The qualitative properties of yogurt are smooth texture, color and aroma in accordance with the additional fruit. White yogurt was for control, dragon fruit and banana yogurt, yellow for mango yogurt and light brown for apple yogurt. Color change in yogurt during storage time $(0,5,10$, and 15 days) was obvious in banana yogurt that turned brown as the week passed, while the other fruit yogurt did not change. Yogurt aroma and texture in day 15 remained typically fragrant and smooth. Banana yogurt had the strongest aroma in each storage time.

The obtained data showed that different fruits added in each storage time affected the product's free fatty acidand lactic acid $(P>0.01)$ (Table 2). Free fatty acid is an independent fatty acid unbound by triglyceride and serves as the parameter of product quality assessment. The highest and the lowest free fatty acid was in control stored for 15 days (22.885\%) and in mango yogurt stored for 10 days (17.588\%), respectively. The longer storage time, the higher free fatty acid content in plain and dragon fruit yogurt. The highest free fatty acid in control yogurt was assumedly due to the more optimum bacteria performance without additional fruit, while fruit yogurt had a substance that inhibited hydrolysis and oxidation supported by bacteria. Hydrolysis and oxidation gave a strong characteristic and flavor and might be the precursor of other substances. It was in line with Gurakan and Altay (2010) that typical aroma and texture of yogurt was the result of microorganism performance.

The highest and lowest lactic acid was in mango yogurt stored for 15 days (21.293\%) and plain yogurt stored for 10 days (13.915\%), respectively. Lactic acid in yogurt was formed after milk inoculation with bacteria starter; Streptococcus thermophillus grew up to $90 \%$ of other bacteria. The next two hours, Streptococcus thermophillus released lactic acid, carbon dioxide and formic acid. Lactobacillus bulgaricussynergized to stimulate faster growth and grew after the milk turned acidic, while Streptococcus was inhibited due to lactic acid accumulation. Lactobacillus bulgaricus played role to the decrease up to $\mathrm{pH}$ 4. On the other hand, proteolytic activity of Lactobacillus bulgaricus resulted in peptide and amino acid stimulation to be used by Streptococcus thermophillus. Yogurt started to coagulate due to $\mathrm{pH}$ decrease.

Table 1.Composition of Cow Milk Yogurt with Different Fruits Addition

\begin{tabular}{lcccc}
\hline Treatment & Water content & Total solids & Fat content & Protein content \\
\hline Control & $87.776 \pm 0.545^{\mathrm{c}}$ & $12.724 \pm 0.54^{\mathrm{a}}$ & $4.516 \pm 0.39^{\mathrm{c}}$ & $2.564 \pm 0.358^{\mathrm{a}}$ \\
P1 (Yogurt + dragon fruit) & $86.372 \pm 0.558^{\mathrm{ab}}$ & $13.628 \pm 0.558^{\mathrm{bc}}$ & $3.698 \pm 0.2155^{\mathrm{b}}$ & $2.712 \pm 0.488^{\mathrm{a}}$ \\
P2 (Yogurt + mango) & $86.892 \pm 0.557^{\mathrm{bc}}$ & $13.108 \pm 0.557^{\mathrm{ab}}$ & $3.178 \pm 0.177^{\mathrm{a}}$ & $3.304 \pm 0.241^{\mathrm{b}}$ \\
P3 (Yogurt + apple) & $85.614 \pm 0.706^{\mathrm{a}}$ & $14.376 \pm 0.706^{\mathrm{c}}$ & $3.906 \pm 0.233^{\mathrm{b}}$ & $3.504 \pm 0.459^{\mathrm{b}}$ \\
P4 (Yogurt + banana) & $85.624 \pm 0.791^{\mathrm{a}}$ & $14.376 \pm 0.791^{\mathrm{c}}$ & $3.554 \pm 0.346^{\mathrm{b}}$ & $3.594 \pm 0.275^{\mathrm{b}}$ \\
\hline
\end{tabular}


Table 2. Free Fatty Acid and Lactic Acid of Yogurt with different additional fruits and storage time

\begin{tabular}{lcccccccc}
\hline & \multicolumn{3}{c}{ Free fatty acid (\%) } \\
\cline { 2 - 9 } Treatment & \multicolumn{3}{c}{ Storage time (days) } \\
\cline { 2 - 9 } & 0 & 5 & 10 & 15 & 0 & 5 & 10 & 15 \\
\hline Control & $20.435 \pm$ & $21.437 \pm$ & $21.433 \pm$ & $22.885 \pm$ & $16.305 \pm$ & $15.556 \pm$ & $13.915 \pm$ & $15.344 \pm$ \\
& $0.416^{\mathrm{a}}$ & $0.404^{\mathrm{b}}$ & $0.208^{\mathrm{b}}$ & $0.166^{\mathrm{c}}$ & $0.754^{\mathrm{c}}$ & $0.198^{\mathrm{b}}$ & $0.134^{\mathrm{c}}$ & $0.105^{\mathrm{b}}$ \\
P1 (Yogurt + & $19.304 \pm$ & $20.983 \pm$ & $20.834 \pm$ & $22.773 \pm$ & $14.942 \pm$ & $14.697 \pm$ & $13.934 \pm$ & $16.523 \pm$ \\
dragon fruit) & $0249^{\mathrm{a}}$ & $0.271^{\mathrm{b}}$ & $0.197^{\mathrm{b}}$ & $0.247^{\mathrm{c}}$ & $0.307^{\mathrm{c}}$ & $0.106^{\mathrm{b}}$ & $0.032^{\mathrm{a}}$ & $0.101^{\mathrm{d}}$ \\
P2 (Yogurt + & $17.989 \pm$ & $19.739 \pm$ & $17.588 \pm$ & $19.485 \pm$ & $16.161 \pm$ & $14.918 \pm$ & $14.294 \pm$ & $21.293 \pm$ \\
mango) & $0.584^{\mathrm{a}}$ & $0.404^{\mathrm{b}}$ & $0.418^{\mathrm{a}}$ & $0.143^{\mathrm{b}}$ & $0.335^{\mathrm{c}}$ & $0.251^{\mathrm{b}}$ & $0.201^{\mathrm{a}}$ & $0.139^{\mathrm{d}}$ \\
P3 (Yogurt + & $19.565 \pm$ & $19.731 \pm$ & $19.276 \pm$ & $18.044 \pm$ & $14.509 \pm$ & $14.225 \pm$ & $14.294 \pm$ & $17.856 \pm$ \\
apple) & $0.340^{\mathrm{c}}$ & $0.303^{\mathrm{c}}$ & $0.108^{\mathrm{b}}$ & $0.106^{\mathrm{a}}$ & $0.292^{\mathrm{c}}$ & $0.285^{\mathrm{b}}$ & $0.201^{\mathrm{a}}$ & $0.037^{\mathrm{d}}$ \\
P4 (Yogurt + & $21.517 \pm$ & $22.575 \pm$ & $21.552 \pm$ & $22.207 \pm$ & $15.671 \pm$ & $16.278 \pm$ & $15.581 \pm$ & $19.236 \pm$ \\
banana) & $0.398^{\mathrm{a}}$ & $0.298^{\mathrm{b}}$ & $0.343^{\mathrm{a}}$ & $0.148^{\mathrm{b}}$ & $0.366^{\mathrm{b}}$ & $0.104^{\mathrm{d}}$ & $0.156^{\mathrm{d}}$ & $0.229^{\mathrm{d}}$ \\
\hline
\end{tabular}

After 4 hours, balance among population was reached. The final fermentation had 1.2-1.4 \% acidity (Gurakan and Altay, 2010). Yildiz (2010) explained a more simple process of lactic acid formation; it was produced by bacteria by dissolving glucose into lactic acid as metabolic product so milk acidity increased and coagulated known as denaturation process.

Yogurt storage is significantly affected by the temperature. This research measured qualitative (color, texture and aroma) and quantitative properties (lactic acid and free fatty acid) on $0,5,10$ and 15 days at $5^{\circ} \mathrm{C}$. Result indicated the effect of storage time on lactic acid and free fatty acid. Yogurt stored for 5 days was still consumable considering the data of qualitative and quantitative properties assessment. In qualitative observation yogurt stored for 15 days showed similar texture, aroma and color to that of 0 day (despite color change in banana yogurt). Accordingly, this research stated that storage at $5^{\circ} \mathrm{C}$ for 15 days resulted in consumable yogurt.

In line with Hayaloglu et al. (2007), storage temperature significantly affected yogurt storage time. Stored at $25-30^{\circ}$, yogurt only stands for one day, but 5 days at $7^{\circ} \mathrm{C}$ and 10 days at $4^{\circ} \mathrm{C}$. Slight difference with this research is the additional fruit lengthens the storage time. The longer storage time was due to the increased acidity as reported in the previous findings. Yildiz (2010) stated that longer storage time in yogurt was due to increasin acidity that prevent the proliferation of patogen bacteria. Increasing acidity occurred because bacteria digested milk sugar then released lactic acid as metabolic product thereby increasing milk acidity and causing coagulation known as denaturation process. Longer storage time of yogurt added with fruit might due to higher acidity as well as metabolic bacteria or the fruit acidity.

\section{Conclusions}

Result showed that cow milk yogurt added with different fruits affected composition (total solids, water content, crude fat and crude protein) and characteristics (lactic acid and free fatty acid). Fruit addition affected yogurt product and resulted in yogurt with relatively longer storage time.

\section{References}

Cakmakcii SBC, T Turgut and M Gurses. 2012. Probiotic properties, sensory qualities, and storage stability of probiotic banana yogurts. Turk. J. Vet. Anim. Sci. 36(3):231-237.

Chandan RC. 2006. History and Consumption. In : RC Chandanet al.,(Eds), Manufacturing yogurt and fermented milks. Blackwell Publishing. Oxford. Pp 4-14.

Guarner FG, G Perdigon, G Corthier, S Salminen, B Koletzko and L Moreli. 2005. Should Yogurt 
Culture be Considered Probiotic. British Journal of Nutrition. 93(6):783-786.

Gurakan GC and N Altay. 2010. Yogurt Microbiology and Biochemistry. In: Development and Manufacture of Yogurt and Other Functional Dairy Product. F. Yildiz (Ed). CRC Press, Taylor \& Francis Group.Boca Raton, USA. Pp. 98-116

Hayaloglu A, I Karabulut, M Alpaslan and G Kelbaliyev. 2007. Mathematical Modeling of Drying Chacarteristics of Strained Yogurt in Convective Tyoe Tray-Dryer. Journal of Food Engineering. 78(1):109-117.

Irvine SL., R Hummelen, S Hekmat, CW Looman, JDF Habbema and G Reid. 2010. Probiotic Yogurt Consumption is Associated with An Increase of CD4 Count Among People Living with HIV/AIDS. Journal of clinical gastroenterology. 44(9):201.

Kolars JC, MD Levitt, M Aouji and DA Savaiano. 1984. Yogurt-An Autodigesting Source of Lactose. New England Journal of Medicine. 310(1):1-3.

Lee $\mathrm{W}$ and J Lucey. 2010. Formation and physical Properties of yogurt. Asian-Aust. J. Animal. 23(9): 1127-1136.

Magenis RB, ES Prudencio, RDMC Amboni, NGC Junior, RVB Oliveira, V Soldi and HD Benendet. 2006. Compotition and Physical Properties of Yogurt Manufacture from Milk and Whey Cheese Concentrated by Ultrafiltration. International journal of Food Science. 41(5):560-568.

Mahmood A, N Abbas and AH Gilani. 2008. Quality Stirred Buffalo Blended Apple and Banana Fruits. Park. J. Agri. Sci. 45:275-279.

Marete S, RJS Blanchemanche and E FeinblanttMeleze. 2010. Functional Food, Uncertainly and Consumers Choices : A Lab Experiment with Enriched Yogutys for Lowering Cholesterol. Food Policy. 35(5):419-428.
McKinley MC. 2005. The Nutrition and Health Benefits of Yogurt. International of Dairy Technologi. 58(3):129-137.

Mulyawanti I, KT Dewandari and Yulianingsih. 2008. Pengaruh Waktu Pembekuan dan Penyimpanan terhadap Characteristics Irisan Buah Mango Arumanis Beku. J. Pascapanen. 5(1):51-58.

Ozer B. 2006. Production of Concentrated Products. In : A. Tamime (Eds). Fermented Milk. Blackwell Science Ltd. New York. USA. Pp 28-155.

Rijkers GT, S Bengmark, P Enck, D Haller, U Herz, M Kalliomaki, S Kudo, I Lenoir-Wijnkoop, A Mercenier and E Myllyluoma. 2010. Guidance for Substantiating the Evidence for Beneficial Effects of Probiotics: Current Status and Recommendations for Future Research. The Journal of nutrition. 140(3):671S.

Steel RG and JH Torrie. 1996. Principles and Procedurs of Statistics. Published, McGraw-Hill Book Company.

To LV, N Ngu, ND. Duc, DTK Trinh, NC Thanh, DVH Mien, CN Hai and TN Long, Eds. 2000. Quality Assurance System for Dragon Fruit Quality assurance in agricultural produce. In: Quality Assurance in Agricultural Produce. G.I. et al., (Ed). ACIAR Proceedings 100. Vietnam. Pp. 111110.

Vrese MD. 2009. Health Benefits of Probiotics and Prebiotics In Women. Menopause International. 15(1):35-40.

Yildiz F. 2010. Overview of Yogurt and Other Fermented Dairy Product. In: Development and Manufacture of Yogurt and Other Fucntional Dairy Product. F. Yildiz. CRC Press, New York, USA. Pp:1-46. 